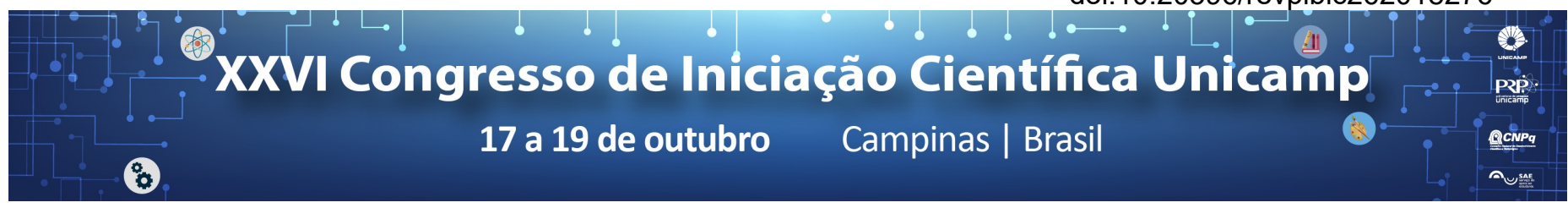

\title{
Development of transport systems of quinolone class antibiotics through outer membrane vesicles (OMVs) in Gram-negative bacteria
}

\section{Carlos F. M. Silva*, Marcelo Lancellotti.}

\begin{abstract}
Multi-resistance to antibiotics in Gram-negative bacteria has been reported in several studies, which make more effective methods of controlling and eliminating these bacteria necessary. To overcome multiresistant profiles, we used OMVs (Outer Membrane Vesicles) as carriers of levofloxacin to encapsulate and transport the drug from the extracellular medium into the cell, overcoming resistance barriers and inhibiting cell reproduction machinery. Prepackaged formulations in this manner were quite effective and, in some cases, totally inhibited bacterial growth by making the drug efficient again.
\end{abstract}

\section{Key words:}

Outer membrane vesicles, Neisseria meningitidis, Nanovaccine.

\section{Introduction}

It has been observed all over the world the emergence of bacteria with a multiresistant profile to fluoroquinolones, bactericidal agents that act by inhibiting the activity of DNA Girase and Topoisomerase IV, enzymes fundamental for the replication of bacteria. Among the mechanisms of resistance are changes in the level of permeation of antibiotics in cells (KUHNKE \& LODE, 2004). Although resistance to the drug is not yet very great, it can become a major problem if its use is reckless: the consequence of excessive use of quinolones is the appearance of bacterial multiresistance (Heffelinger, 2000).

To obtain an even greater spectrum of action on resistant strains, the purpose of this work is to use OMVs (outer membrane vesicles) as carriers of levofloxacin, a synthetic antimicrobial agent of fluoroquinolones. The proposal is to cause the vesicles to encapsulate the drug and transport it from the extracellular medium into the cell by overcoming antibiotic resistance barriers to inhibit cell reproduction machinery.

\section{Results and Discussion}

The outer membrane vesicles used in this work were obtained from Neisseria meningitidis. Four batches of formulations were prepared, each with variable concentrations of levofloxacin, OMV, water and ethanol. The Encapsulation of Levofloxanin was passively done under continuous stirring at 200 rpm for 12 hours at room temperature until the formulation was achieved with satisfactory results.

To test the effect of formulations on inhibition of bacterial growth, we used eight strains commonly used in antibiogram and Minimum Inhibitory Concentration (MIC) tests. For both tests, the control group is levofloxacin free in the medium, ie, non-encapsulated

From the results of the Antibiogram, the most sensitive strains were selected, as well as the most promising formulations for the MIC test. Early tests indicated the need to increase drug concentration and OMVs in the final formulation. For the MIC trial, the initial concentration of levofloxacin was $2 \mu \mathrm{g} / \mathrm{ml}$.

The following table refers to the best results of the bacterial growth inhibitory minimum concentration test.
The acronyms 4F1 and 4F3 mean fourth batch formulation one, and fourth batch - formulation three, respectively. These two formulations contain levofloxacin encapsulated in OMV, and Control is the formulation without OMV.

Table 1. MIC Results.

\begin{tabular}{|l|c|c|c|}
\hline \multicolumn{4}{|l|}{ Inhibitory Minimal Concentration } \\
\hline Bacteria & $4 \mathrm{~F} 1$ & $4 \mathrm{~F} 3$ & Control \\
\hline S. epidermidis & $2 \mu \mathrm{g} / \mathrm{ml}$ & $1 \mu \mathrm{g} / \mathrm{ml}$ & No inhibition \\
\hline P. aeruginosa & $0,25 \mu \mathrm{g} / \mathrm{ml}$ & $0,5 \mu \mathrm{g} / \mathrm{ml}$ & $\begin{array}{c}\text { Parcial } \\
\text { inhibition }\end{array}$ \\
\hline RIB1 & $1 \mu \mathrm{g} / \mathrm{ml}$ & $1 \mu \mathrm{g} / \mathrm{ml}$ & No inhibition \\
\hline S. aureus & $2 \mu \mathrm{g} / \mathrm{ml}$ & No inhibition & No inhibition \\
\hline
\end{tabular}

\section{Conclusions}

The control was not able to fully inhibit bacterial growth in any of the cases while OMV-containing formulations as drug carriers proved to be very effective in inhibition. This shows us that OMVs can overcome the barriers of antibiotic permeability and transport the drug into the cell where it will block DNA replication machinery, preventing bacterial reproduction.

\section{Acknowledgement}

My thanks to CNPq, FAPESP, SAE, and to Professor Marcelo Lancellotti and his team for guidance and encouragement.

HEFFELFINGER, J. D.; et al. Management of community-acquired pneumonia in the era of pneumococcal resistence: a report from the drug-resistant Streptococcus pneumoniae. Arc. Interm. Med. V. 160, p. 1399-1408, 2000.

KUHNKE, A.; LODE, H. Fluoroquinolones and lower respiratory tract infections. Eur. Respir. Mon. V. 28, p. 94-112, 2004. 